\title{
Historical Learning: Digital Map Implementation to Improve Historical Explanation Ability
}

\author{
Monika Sari*; Akhmad Arif Musadad; Nunuk Suryani \\ Department of Teacher Training and Education, SebelasMaret University, Indonesia \\ Email: Moenicha66@gmail.com
}

http://dx.doi.org/10.18415/ijmmu.v5i2.128

\begin{abstract}
One of historical learning goal in Indonesia is to instill knowledge of historical facts and insights concerning past events, and character attitudes and values. It will produce quality outputs that include understanding the historical event, imitating the wisdom, and the wisdom of the historical offender. Therefore, the improving of the cognitive ability requires easy, cheap, interesting and interactive learning media is needed to improve the ability of historical explanation in accordance to the development of Information Communication and Technology (ICT). Learning media in accordance to historical material is needed to be applied in the historical learning digital-based. This research was conducted in SMA Negeri 5 Surakarta with the research subject of class XI MIPA 1 research which 32 people. This research is an experimental research. The data collection used a digital assessment questionnaire and an instrument with 10 questions to measure the increase in historical explanations. This study aims to see the application of digital-based maps to improve the ability of historical explanation. The research result shows that there is an increase in the ability of historical explanation by using digital maps.
\end{abstract}

Keywords: Historical learning; Digital map; Historical explanation

\section{Introduction}

The development of information, technology and communication has major influence on the student development and their thinking patterns in the acquisition of knowledge. Rosenberg (Sutopo 2012: 17) with the development of ICT, there are five shifts in the learning process, they are: (1) from training to appearance, (2) from classroom to where and anytime, (3) from paper to "online", (4) physical facilities to network facilities, (5) from time cycle to real time. Students are in globalization era which is marked by the rapid development of technology and information. Thus, the business of acquiring knowledge has also shifted from the conventional to the digital.

Conventional learning will make teacher centered learning. Santrock (2011: 162) mentions that teacher-centered learning does not get criticism. Critics say that teacher-centered learning often causes passive memorizing learning and insufficient opportunities to build knowledge and understanding. Education that is conventional will make the goal of learning itself very difficult to achieve. One achievement of learning objectives can be done with the use of media in the historical learning. 
Asyhar (2012: 15) argues that the quality of learning needs various efforts to make it happen. These efforts are related to the various components involved in learning, one of them is the use of learning media. Arsyad (2014: 16) with the shift of learning paradigm from behavioristic to constructivistic make learning must refer to student centered learning so to support this learning paradigm is needed by educator and teacher which professional, skilled and creative in using and developing learning media. Anita (2012: 72) states that a teacher must be able to determine the most appropriate media for the learning implementation activities. Digital media learning is able to achieve the learning goal that is historical explanation ability.

Explanation is historical explanation that not only answers what, where, when, and who but also needs to answer how and why that needs to be analyzed critically in a fact of the event so that it can be known the cause of an event. It will make the consequences of the cause in the end the series events that can be explained and described well and chronologically. Improving the ability of historial explanation of learners can be done through the use of digital map media.

Based on the study of Hmelo and Howadr S (2006: 21) the use of video in learning and stimulated by usage will make students construct causal explanations, effective reasons for a problem and make self-centered learning means student-centered. It shows that the use of audio visual media in the form of digital maps can build a causal explanation of students where learning becomes centered to students in accordance to constructivism learning theory so the ability of students' historical explanation can be improved.

\section{Literature Review Historical Learning}

Learning is a vital human activity and will continue to be done as long as the human being is alive. Human cannot live as a human being if he is not educated or taught by other humans. Learning is an internal process (a purely internal event) that cannot be seen clearly. The process takes place inside a person who is undergoing a learning process (Thobroni., 2013: 16-17). Learning is a process that will change the way people behave when they have experienced the learning process in a long time. Sagala (2010: 62) states that learning as a learning process is built by teachers to develop thinking creativity that can improve students' thinking ability, and can improve the ability to construct new knowledge as an effort to improve good mastery of the subject material.

History is a past reconstruction. The historical reconstructed is anything that people already think, do, feel and experience (Kuntowijoyo., 2001: 18-19). In line with the above opinion, history means the human past (Gottschalk., 1975: 27). History is closely related to the past life. To reconstruct the past then a historian must have authentic facts and data to reveal a historical event. History is anything that happens in a generally accepted sense that is the human history. The material studied is the traces left by human existence in the world, ideas, traditions, and social institutions, language, books, human production goods, the physical man himself, the physical remains of human, his thoughts, his feelings, and his actions (Kochhar., 2008: 2).

Historical learning is learning that emphasizes the cultivation of values and attitudes and character formation. It is the students purposes who have experienced the process of historical learning is able to apply the moral values that can be from a historical learning material. Hermanu Joebagio (Brian., 2015: ix) historical learning is the process of internalizing the past events value, in the form of origins, genealogies, collective experiences, and exemplary of historical perpetrators. The lesson is designed to form a wise and wisdom personality, hence the historical learning needs a design that will produce quality 
output that includes understanding the events of the nation's history, imitating the wisdom, and the wisdom of the historical perpetrators.

Agung and Wahyuni (2013: 55) History is a subject that instills knowledge, attitudes, and values regarding the process of change and development of Indonesian society and the world from the past to the present day. According to Wineburg (2006: 6), why history need to be taught in school because history has a new potential, some of it manifested to make us human beings, things that cannot be done by all other subjects in the school curriculum. Historical learning is often characterized by memorizing dates, years, places, figures, and sequences of past events (Hamid., 2014: 39).

Historical Learning is (a) gaining knowledge of historical facts, (b) obtaining an understanding or appreciation of past events, periods or societies; (c) gaining the ability to assess and criticize the writing about history; (d) learning how to conduct historical research; (d) learning how to write history (Garvey and Krug 2015: 2).

\section{Digital Map}

The use of media is very important in the historical learning. Sulistyo (2011: 1) states that in the process of teaching and learning, one thing that need to be prepared in order to support the delivery of learning materials and the success of an education that is education media. Arsyad (2014: 19) states that the use of learning media at the learning orientation stage will greatly help the effectiveness of the learning process and delivery of messages and content of the lesson at that time. In addition, to generating student motivation and interest, learning media can also help students improve their understanding, present data attractively and reliably, facilitate interpretation of data, and compact information.

Nafi'ah dan Indah (2017: 104) exciting and interesting historical lessons can be done by using technology, especially information and communication technology in digital learning. With digital learning, students can reconstruct their own knowledge through meaningful processes. Umam (2013: 101) Digital media can present learning materials in contextual, audio and visual in an interesting and interactive. It is also supported by the rapid development of computer technology. Ma'ruf, Nunuk Suryani dan Sudianto (2017: 76) state that the use of digital media can increase the interest and achievement of historical learning. A digital map is a map that is applied in digital form so it's use can be through the learner's laptop with a fascinating design and appearance. Atno (2011: 215) Submission of historical lesson materials by using computer media can arouse the desire, new interest of students, reduce boredom in receiving lesson materials and more motivate students in learning.

Garvey and Mary Krug (2015: 93) there are two basic ways of using maps in historical learning, they are (a) as illustrations or visuals that can help students understand the topic or discussion. If the teacher decides not to use a map or atlas it assumes that his or her students have been able to imagine the contents of the map in his mind, (b) as a historical learning resource that deals specifically with historical events such as warfare, migration, trade routes. Sanaky (2013: 105) The advantages of the map and globe when used as a medium in the learning process is one of the maps and globe is very important to mke concrete of abstract messages. By making concrete the abstract message that can increase student explanation ability.

Using the map as a way to communicate about what happens at certain times so it opens the door to learning. In addition, the maps are helpful in motivating students (Hewitt et al.,: 2). Hidayat (2011: 60) maps make it easier to search locations and the creation of digital map applications can replace the use of map in the form of paper. Based on research Sari (2014: 77) shows that there is an increase in learning by using an interactive map media that is (1) understanding of student material in learning; (2) Ability to 
show location; (3) Student activity in learning; (4) Improving learning result. The map is able to improve the ability of explanation and students' understanding of the historical subject material, with the understanding that students will be able to perform explanations based on the understanding that they have acquired.

\section{Historical Explanation}

R.G Collingwood (Daliman., 2012: 68) argues that the superiority of a historian as compared to other scientists is "re-thinking them in his own mind". It means that historians must be able to break through the minds of the historical perpetrators by trying to revive the thinking of the historical perpetrators by trying to revive the thoughts of the historical perpetrators in their own thoughts. In other words imaginatively, the historian tries to put his character into or as historical perpetrators. This is seen as the basis in the way of historical thinking (historical thinking) which became the starting point of how to explain the history (historical explanation). This implies that the historical explanation is not merely a description but rather to how the historical event is explored so to revive the event and arrange it through the facts found and then linked in a cause-by-effect of one event to another so that explanation (explanation) of history can be achieved.

Historical Explanation (historical explanation) is defined as an attempt to explain the whole causality (Kartodirdjo., 2014: 53). Interpretation and interpretation is a continuation of the historical explanation itself. The necessary explanation is an explanation by assembling facts in a causal relationship (cause and effect). In the historical causality can be distinguished into a general cause (cause, fundamental cause) and a special cause (direct cause, immediate cause). Causal law reminds us that every phenomenon is the result of the previous cause, so causality can be regarded as broad and deep explanation problem which are all historical methodologies. Pranoto (2014: 43) Explanation or explanation means explanation.

In the further meaning, Explanation are clear and understable (to make plain, clear and understable) the readers or human. Explanation goal is making the answerer be satisfied with the answer and the questions. Sjamuddin (2012: 149) explain or explanation from the past. History alsocan not be separated from the explanation ability from past event. Daliman (2012: 67) Explanation (explaination) that included why and how need the more concern because it is the characteristics from the historical explanation will be seen.

Hung (2014) Explanation can fix the historical mistake with grow the understanding by historic context which can develop again the history. Brook (2007) critic evaluation has role in the explaining why in the historical explanation. Daliman (2012: 67) states that historical science has explanation task, the task is explaining the historical event. Agung and Sri Wahyuni (2013: 61) Every subject has the unique characteristic, one of the historical subject characteristic is the principal of cause and effect.

Hammer (2008) states that the historical explanation aspect (historical explanation) related to cause and effect. Agung and Wahyuni (2013: 61) Every subject has the unique characteristic. Cognitive ability that is developed by students impacted to the improving of students explanation ability. Historical explanation is very important to be improved in the learning in order to make students thinking analytically when answer the historical event by the development knowledge after historical learning process.

The important of historical explanation in the learning, it makes students can be able to improve historical explanation with the using of digital-based map media. Griffin, dkk (2008: 348-358) map is the popular and effective resources in historical learning. Through visualitation map, student and teacher can 
explore and learn the complex and conceptual movement that include the settlement ang pattern of migration, the important of physical boundariesand geomorphoology and diffusion of goods and ideas. Digital-based Map is map that dikonvesikan in the digital form whic is ran by laptop can improve historical explanation ability.

\section{Methodology}

This research is done at SMAN 5 Surakarta at class XI MIPA 1. The research sample are 32 people which is taken by using multi- stage cluster sampling random method. The using research method is experiment of One Group Pretest-Posttest design. Sugiyono (2015: 74) One Group Pretest-Posttest design, in this design is being pretest before give treatment, the the result can be known accuratly because compare with the condition before the method using. The collecting data technique by questionnaire and test instrument. Data analysis technique through paired t-test uses SPSS20.

\section{Result And Discussion Digital Map Implementation to Improve Historical Explanation Ability}

Implementation of digital map is done with once implementation step. Material in the digital map is material about General Attack at Solo in 1949. To see the adaption of digital map media for learning is used questionnaire to assest digital map, while to measure the historical explanation ability uses instrument with 10 questions. The level of student's historical explanation ability is measured with three explanation indicators, they are (1) the ability to explain (2) ability to answer cronologically and (3) ability to relate the answer causalically (cause-effect).

Implementation of digital map is collaborated by Problem Based Learning (PBL) model. Shoimin (2014: 24) as innovative learning model that can be used in the learning implementation which has suitable quality with curicullum 2013, such as Problem Based Learning. Sugiyanto (2009: 152) Problem Based Learning (PBL) does not very focus on what the student do (their attitude) but what the student think (their cognition) during they do it. Warsono (2013: 149) Problem Based Learning is type of class management that is needed to support constructivism approach in the learning and learn.

Constructivism approach make learning from teacher centered learning become student centered learning. Santrock (2011: 162) states that teacher centered learning does not get the critics. The critics say that teacher centered learning often cause the passive memorizing learning and inadequateopportunities to develop the knowledge and understanding. The using of PBL model in the learning will help student to develop cognitive ability by problem solving which will be given by teacher. Hosnan $(2014: 301)$ There are 5 Steps in the PBL model; 1) orientate the student to problem; 2) Organize student to learn; 3) guide the individual or group investigation; 4) Develop and serve the work result; 5) Analyze and evaluate problem solving process.

The Implementation Steps of Digital Map is collaborated through PBL Model, as follows:

\section{First Stage: Orientate Student to Problems}

Teacher give 1 problem on the Power Point Slide. With showing the picture that related to Solo General Attack in 1949. Giving the question that related to the showing picture. If there is student in the problem, teacher asks another student to give statement. The teacher will give the classical help through 
the giving of scaffolding. Teacher asks student to give opinion from the problem accuratly with their own language.

\section{Second Stage: Organize Student to Learn}

Teacher divides class become 5 groups. 1 group consists of 5-6 students. Teacher provides digital map media that gaves to every group and canbe seen by student's laptop. Teacher gives task filled problem that must be done and ask student to collaborate in solving that problems. Teacher helps (scaffolding) related to what is experienced by students individually, group or classical. Teacher asks student to work together to collect a various concept and think accuratly the solving strategy that useful for problem solving.

\section{Third Stage: Guide the Individual and Group Investigation}

Teacher asks student to see the relation based on data/information related to the development. Student observes digital map media that shared to every group. Teacher guides student to collect data/information related to problem solving by digital map media.

\section{Fourth Stage: Develop and Serve the Work Result}

Teacher asks student to prepare the report of group discussion result neatly, accuratly and sistematically. Teacher gets round to look close the student work to arrange the report of discussion result, and give help if needed. Teacher asks student to decide the group representative by discussion to present the report in front of the class.

\section{Fifth Stage: Analyze and Evaluate Problem Solving Process}

Teacher involves student to evaluate the group answer and the suggestion from other group to make a deal if the answer is correct. Teacher pushs student to involve actively in the group discussion and also help each other to solve that problem. Teacher takes care and pushs student to involve in the discussion. Besides, the other groups give opinion and complete the presentation to be perfect. Teacher collects all of the discussion results in every group. With answer-question, teacher directs student to make conclusion about that problem.

After learning process finish so students get questionnaire to assest the adaptation of digital map media using in the learning process. The assesment aspect in the questionnaire of digital map is learning aspect, design aspect and appereance format aspect. Based on Implementation that is done to assesment questionnaire of digital map gets avarage value of 4.4. Based on that result, the adaptation of digital map is good categorized. This is the assesment picture of media questionnaire by student based on frequency distribution: 


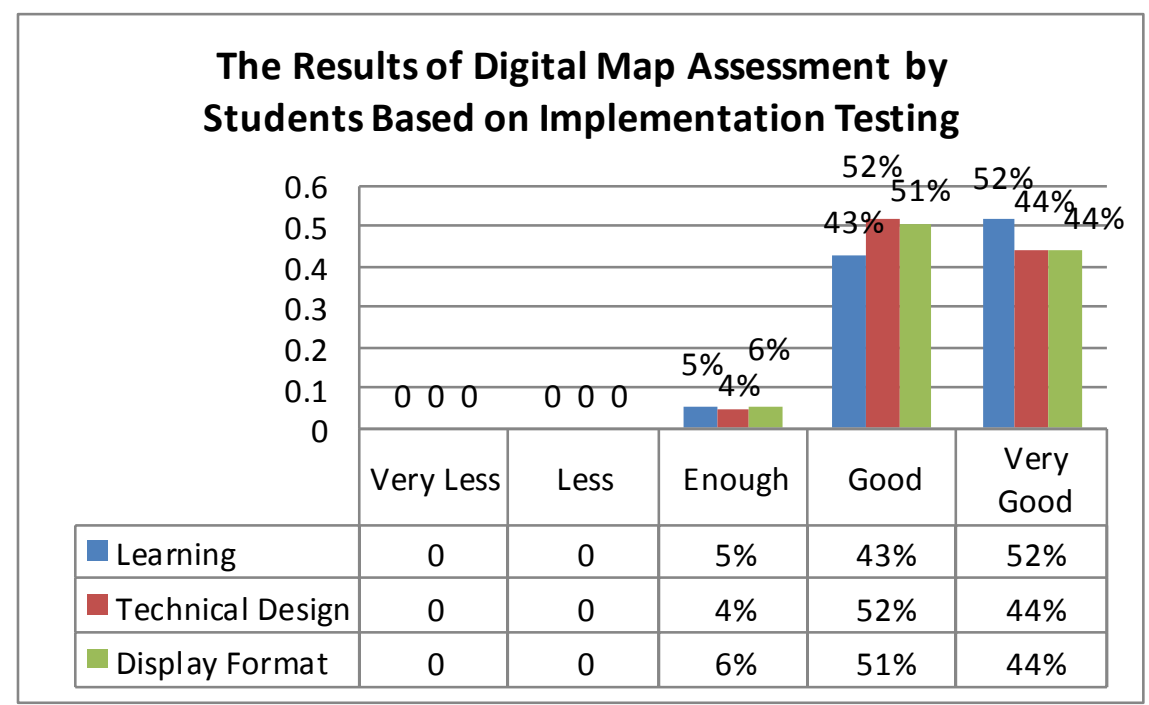

Fig. 1 Histogram of digital map by students implementation testing result by students

The level measurement of student explanation ability uses test with 10 questions. Based on level implementation of historical explanation ability is avarage test result student historical explanation ability on pretest 58.88 , besides the average result of student historical explanation ability posttest is 86.00 . Between two variabel result significant value of 0,008 (smaller than 0,05 ). It means the correlation between before and after the using of digital map is very related and connected in real. Based on t-test of probability value or sig (2-tailed) is 0.000 (Pro $<0,050$ and $\mathrm{t}$ count $=-40.752(\mathrm{t}$ tabel on significancy $=5 \%$, Df 32-1=31; get value of 1,69552. Therefore, the significancy (2-tailed) 0.000 is smaller than 0,05 so can be concluded that there is the improving of ability level to student historical explanation in the using of that digital map in real. The decision tested is rejected Ho.

\section{Conclusion}

Based on research result can be concluded that the using of digital map in the historical learning can improve the student historical explanation ability. The class avarage value before (pretest) is 58.88 after give digital map implementation, there is the ability improving of historical explanation. They are the student avarage value after posttest 86.00 and the big improving of $27 \%$ for the ability of student historical explanation.

From the research result, the writer gives suggestion as follows (1) The media using that creative and innovative is very important in the historical learning; (2) The profer learning media will make easy to achieve the goal; (3) Historical Learning paradigm yang bersifat hafalan can be changed by using media that suitable with technology development in digital era so learning can be attractived and pleasured. 


\section{References}

Agung Leo dan Wahyuni Sri. (2013). Perencanaan Pembelajaran Sejarah. Yogyakarta: Penerbit Ombak.

Anita, Sri. (2012). Media Pembelajaran. Surakarta: Yuma Pustaka.

Arsyad, Azhar. (2014). Media Pebelajaran. Jakarta: Rajawali Pers.

Asyhar, H Rayandra. (2011). Kreatif Mengembangkan Media Pembelajaran. Jakarta: Gaung Perdasa (PS) Press.

Daliman, A. (2012). Pengantar Filsafat Sejarah. Yogyakarta: Penerbit Ombak.

Garvey Brian \& Krug Mary. (2015). Model-Model Pembelajaran Sejarah di Sekolah Menengah. Yogyakarta: Ombak.

Gottschalk, Louis. (1975). Mengerti Sejarah Pengantar Metode Sejarah. Jakarta: Yayasan Penerbit Universitas Indonesia.

Griffin, A,dkk. (2008). Recource-based Learning in Geography the Anthology of Social Studies: Issue and Strategies for Secondary Teachers. Pacific Education Press.

Hamid, Abd Rahman. (2014). Pembelajaran Sejarah. Yogyakarta: Ombak.

Hewitt, Patricia, dkk. Historic Map as Teaching Tools: A Curriculum Guide for Grades 5-8.

Hosnan. (2014). Pendekatan saintifik dan Kontekstual dalam Pembelajaran Abad 21. Bogor: Ghalia Indonesia.

Kartodirdjo, Sartono. (1992). Pendekatan Ilmu Sosial dalam Metodologi Sejarah. Jakarta: Gramedia Pustaka Utama.

Kocchar. S.K. (2008). Pembelajaran Sejarah Teaching of History. Jakarta: Gramedia.

Kuntowijoyo. (2001). Pengantar Ilmu Sejarah. Jogjakarta: Yayasan Bentang Budaya.

Pranoto, Suhartono. (2014). Teori dan Metodologi Sejarah. Yogyakarta: Graha Ilmu.

Sagala, Syaiful. (2010). Konsep dan Makna Pembelajaran Untuk Membangun Memecahkan Problematika Belajar dan Mengajar. Bandung: Alfabeta.

Sanaky, Hujair AH. (2013). Media pembelajaran Interaktif-Inovatif. Yogyakarta: Kaukaba Dipantara.

Santrock, John W. (2011). Psokologi Pendidikan Educational Psycology Edisi 3 Buku 1. Jakarta: Salemba Humatika.

Santrock, John W. (2011). Psokologi Pendidikan Educational Psycology Edisi 3 Buku 2. Jakarta: Salemba Humatika.

Shoimin, Aris. (2014). 68 Model Pembelajaran Inovatif dalam Kurikulum 2013. Yogyakarta: Ar-Ruzz.

Sjamsuddin, Helius. (2012). Metodologi Sejarah. Yogyakarta: Penerbit Ombak. 
Sugiyanto. (2009). Model-Model Pembelajaran Inovatif. Surakarta: Panitia Sertifikasi Guru Rayon 13FKIP UNS Surakarta.

Sugiyono. (2015). Metode Penelitian Kuantitatif, Kualitatif dan R\&D. Bandung: Alfabeta.

Sutopo, Ariesto Hadi. (2012). Teknologi Informasi dan Komunikasi Dalam Pendidikan. Yogyakarta: Graha Ilmu.

Thobroni, Muhammad dan Mustofa Arif. (2013). Belajar dan Pembelajaran Pengembangan Wacana dan Praktik Pembelajaran dalam Pembangunan Nasional. Jogjakarta: AR-Ruzz Media.

Warsono, dkk. (2013). Pembelajaran Aktif: Teori dan Asesmen. Bandung: PT Remaja Rosdakarya.

Wineburg, Sam. (2006). Berfikir Historis: Memetakan masa Depan, Mengajarkan Masa Lalu. Jakarta: Yayasan Obor Indonesia.

\section{Journal}

Atno. (2011). Efektivitas Media CD Interaktif dan Media CD Terhadap Hasil BelajarSejarah Siswa SMA Negeri di Banjarnegara Ditinjau dari Motivasi Belajar. Jurnal Paramita, 21(2): 213-225 [ISSN: 08540039] Hlm. Diaskes pada 28 Agustus 2017.

Brook, Eric C. (2007). The Interrogative Model: Historical Inquiry and Explanation. Journal of the Philosophy of History 1. California Baptist University USA. 137-159.

Hammer, Carl. (2008). Explication, Explanation, and History. Wesleyan University. History and Theory 47: 183-199.

Hidayat, Syam Kurniawan. (2011). Aplikasi Peta Digital Universitas Muhammadiyah Surakarta. Jurnal Komuniti Vol.II No. YJanuari 2011. Diakses pada 6 September 2017.

Hmleo, Cindy E dan Barrows Howard S. (2006). Goals and Strategies of a Problem-based Learning Facilitator. IJPBL is Published in Open Access Format through the Generous Support of the Teaching Academy at Purdue University, the School of Education at Indiana University, and the Educational Technology program at the University of South Carolina. Vol 1.

Hung, Steven Chung Fu. (2014). Public Education Estabilishment in the Earliest Colonial Period of Hongkong: A Historical Re-Constructivist Explanation. Journal of Art and Humanities (JAH), 3(8) Tahun 2014. Diakses pada 1 Oktober 2017.

Ma'ruf Agi, Nunuk \& Sudianto. (2017). Digital Media Based on Macromedia Flash to Increase the Historical Learning Interest of Senior High School Students. American International Journal of Social Science, 6(2). Diakses pada 8 September 2017.

Nafi'ah Ulfatun dan Indah. (2017). Development of Sigil Based E-Book as Media for "Technology and Information for History Learning” Course. Paramita: Historical Studies Journal, 27(1): 103-112. ISSN: 0854-0039, E-ISSN: 2407-5825. Diakses pada 28 Agustus 2017.

Sari, Maya Kartika. (2014). Pengaruh Media Interaktif Terhadap Pemahaman dan Hasil Belajar Siswa Mata Pelajaran IPS Kelas IV SD. Jurnal Premier Educantum, 4(1): 65-78. Diakses pada 28 Agustus 2017. 
Umam, Kaiful. (2013). Penerapan Media Digital dalam Pembelajaran Apresiasi Batik Kelas X SMA Negeri 1 Blega. Jurnal Pendidikan Seni Rupa, 1(1): 100-105.

\section{Copyrights}

Copyright for this article is retained by the author(s), with first publication rights granted to the journal.

This is an open-access article distributed under the terms and conditions of the Creative Commons Attribution license (http://creativecommons.org/licenses/by/4.0/). 